\title{
Youth culture, media and sexuality: What could faith communities contribute?
}

\begin{abstract}
Author:
Anita Cloete ${ }^{1}$

Affiliation:

${ }^{1}$ Department of Practical

Theology and Missiology, University of Stellenbosch,

South Africa

Note:

This article is published

in the section Practical

Theology of the Society for

Practical Theology in

South Africa.

Correspondence to:

Anita Cloete

Email:

acloete@sun.ac.za

Postal address:

Private Bag X1, Matieland

7602, Stellenbosch,

South Africa

Dates:

Received: 23 June 2011

Accepted: 08 Nov. 2011

Published: 14 Feb. 2012

How to cite this article:

Cloete, A., 2012, 'Youth

culture, media and

sexuality: What could faith

communities contribute?',

HTS Teologiese Studies/

Theological Studies 68(2),

Art. \#1118, 6 pages. http://

dx.doi.org/10.4102/hts.

v68i2.1118
\end{abstract}

(C) 2012. The Authors

Licensee: AOSIS

OpenJournals. This work

is licensed under the

Creative Commons

Attribution License.
This article provided an overview of youth culture and how the media shapes youth culture today. Its specific aim was to focus on the access to sexual content that the different forms of media provide and the possible effect that they have on youth culture today. The sexual development of teenagers is one of the most important areas of their journey into adulthood and can easily be influenced by media messages on sex and sexuality. As such, the sexual behaviour of teenagers mostly seems to demonstrate a misconception on sex and sexuality. The author argued that sex and sexuality can also be viewed as theological issues and concluded by offering a few suggestions on how faith communities can become a more relevant and effective partner in fostering a theological understanding of sex and sexuality, especially to the youth.

\section{Introduction}

In this article, I provide an overview of the conceptual understanding of youth and youth culture, followed by a discussion on the relationship between youth and media, with specific reference to the media's portrayal of sex and sexuality. Here, the distinction between sex and sexuality is acknowledged, namely that sex is referring to the biological-based need which is orientated towards procreation and pleasure, whilst sexuality is a much broader term which goes beyond sex and, indeed, need not even include genital sex (Kretzchmar 1998:52). Yet, at the same time, the close link between sex and sexuality is also acknowledged, which makes a total disconnection of these two concepts and realities impossible. I will not use this article to analyse specific films or television programmes with regards to sexual content, as that is a study on its own. Rather, I argue that sex and sexuality can be viewed as theological issues and therefore faith communities can play a significant role in the discussion and education of youth on these issues. I conclude by offering a few suggestions on how faith communities can become a hermeneutical agent and space in which a theological understanding of sex and sexuality is facilitated to teenagers and an alternative voice with regards to human sexuality is heard.

\section{Youth and youth culture}

Before the relationship between youth and the media is discussed, a short overview is necessary in relation to how the social category of 'youth' and their way of living, referred to here as 'youth culture', came into existence. The term 'youth' is relatively new and came into use after the Industrial Revolution; that is, by the late 19th and early 20th centuries. Before that, children were classified as part of the working community and, as such, there was not a sharp distinction between children, youth and adults. The rapid passage from childhood to adulthood had ceased, making way for a new understanding of the young as a cohort in need of specialisation through a liminal stage of education, thereby paving the way for the arrival of the 'adolescent', a group which church and parachurch ministries began giving specific attention to (Root 2007:28). The term 'adolescence' only came into use after 1904, when Stanley Hall wrote a book entitled Adolescence: Its psychology and its relations to physiology, anthropology, sociology, sex, crime, religion and education. The development of youth (teenagers or adolescents) is described as a 'cultural invention' created and driven by the labour market (Kotesky 1991:42). The developments brought about by industrialisation and the labour market led to a separation of children and adolescents from the category of adults and, slowly but surely, a new subculture emerged, namely youth culture. Schools became one of the most important societal structures where youth culture developed rapidly. Youth culture has also been referred to as an anti-culture, which is in opposition to the adult culture (Nel 2000:32), whilst the term 'subculture' has been used by sociologists because it represents the most visible aspect of the youth experience. According to Miles (2000:6), youth subculture offers young people a sense of identity which is ascribed to them by school, work and class environments. It offers them the opportunity to experience a sense of social reality that is independent and different from the adult world and culture into which they are born. 
Another term used in connection with youth is 'transition'. Youth is described as people of a certain age (e.g. 12-18 years) who, in what seems to be a linear fashion, pass through certain stages of life in an almost predictable manner. Miles (2000:11) comments on this conceptual understanding by saying that youth is related to age, but is not described by it. He proposes that a better conceptual understanding of youth is not to focus on the characteristics of young people of a particular age, but rather to try and conceptualise youth as a way of life which is constructed through social processes such as family, the labour market, school and other cultural environments. As a distinctive way of thinking, living, doing and talking, youth culture is better described retrospectively because it is never static and is changing all the time. Nel (2000:28-29) warns that although youth culture is not so easily defined and is rapidly changing, it is no excuse to avoid trying to describe and understand youth culture. Youth through their way of living is sometimes seen as a barometer and a mirror of the society and world in which they live. As McRobbie (1993:420) puts it: 'Young people are constantly making statements of one form or another and these statements take different shapes under different historical conditions.' The question is therefore which statements are young people currently making and why? The complexity in defining youth and youth culture is acknowledged in this article; however, I would like to focus here on the understanding of youth culture as a way of living.

The question could be asked as to how youth and youth culture is perceived? The establishment of 'youth' as a distinct life phase and social cohort in society leads to social concerns about the behaviour (lifestyle or culture) of the youth. There was more control over children when they were part of the workforce, but now that youth are on their own, youth crime has increased. Muncie (2004) says:

Growing concern was expressed not simply about the need to control criminality, but about the need to tackle a premature precocity symbolized by promiscuity, irreligion, and knowledge of the adult world and its pleasures. (p. 56)

In short, the problem was viewed as having as much a moral as a criminal character. France (2008:1) describes the anxiety over youth as a social problem and concern over social integration and youth delinquency. As youth became an established and recognised group in society, their way of living and new ideas as part of the youth subculture were seen both as sources of social change and as a potential threat to the existing social order. This is also referred to as the 'moral panic' over the youth (Krinsky 2008:1). It seems that the development of youth and youth culture were always accompanied by ambivalence.

From this short reflection on the conceptual understanding of youth and youth culture, it is evident that both these terms are relatively new and not that easy to define. The separation between youth subculture and adult culture has increased over time, with the youth often being perceived as the 'other'. As France (2008:1) puts it, 'Throughout modernity the youth question or "what is to be done about young people" has been dominated by adults' anxieties over youth as a social problem.' This leads to a situation where youth are sometimes perceived as 'too different' and an enigma at home, in the Church and in broader society. The aim of this article is to counter this kind of attitude of seeing youth as too different because of their way of living (youth culture) and encourage, especially faith communities, to find ways to begin, as Mueller (2006) phrases it in the title of his work, Engaging the soul of youth culture: Bridging teen worldviews and Christian truths.

I would like to propose three factors that should be kept in mind when trying to engage with youth culture. Firstly, it is important to remember that culture is part and parcel of a person's very being; that is, it is how people understand themselves, what they believe and how they choose to live their lives. Culture can also be seen as the surface medium through which people (including youths) express their convictions and their collective identity. Secondly, it could be helpful to keep in mind that culture manifests on two levels, namely the empirical level which can be observed and that of the underlying worldview (Mueller 2006:116). Both these levels - the empirical and the underlying worldview - need to be taken into consideration in order to get some understanding of the culture, the beliefs and value systems behind the empirical actions which we observe. This understanding is very helpful in any engagement with youth culture. If the view is taken that youth culture is expressed by the empirically observable behaviour of youths (e.g. through language and slang, clothing style, tattoos, body marks, music, films and television shows, art, heroes and role models), it is important to also take time to understand the worldview behind this lifestyle (Mueller 2006:118-119). This requires some kind of an understanding and relationship with the youth and a non-judgemental attitude when engaging with them. Thirdly, culture is learned and shared and therefore does not exist in a vacuum (Mueller 2006:116). The context in which a certain culture develops and is lived needs to be taken into consideration. Youth culture can be seen as portraying something of the broader society in which they live. In that sense youth culture can be viewed as an index of social norms and values, which are contextualised through different options, diversity and choice. This also leads to a greater diversity of attitudes towards sexual morality than has been the case in the past (Bishops' Group 2003:1). In the modern and postmodern era, people make choices - even moral choices - in terms of individual preference. How does this relate to sexual matters and the youth? The answer is that most young people's lives are shaped in this context of variety and diversity of choice and lifestyle. This further indicates how moral values on sexual matters are shaped and how youngsters make these choices based on personal preference. Today, people construct 'their own world' by the selections they make from the huge variety of choices that is available and, because the choices they make are so different, a diversity of lifestyles is the inevitable result. These choices are also made in relation to personal fulfilment and emotional happiness as goals of human existence. Today there is also money to be made from 'sex', which leads to 
an 'increasingly widespread and graphic depiction of sexual activity of all kinds in books, newspapers, magazines, the cinema, television and the internet' (Bishops' Group 2003: 3-5). In this regard, Lesley Orr (2004:8) also writes about the global sex industry, defining it as 'the activities which legally or illegally market and sell sexual products in organised form and which makes profits from the sexual use of peoplechildren, women and men'. In such context, a variety of sexual activity and behaviour becomes acceptable and the message coming from the media is mostly not in favour of traditional sexual morality (Bishops' Group 2003:7).

\section{How the media influences and shapes youth culture, with specific reference to sex and sexuality}

Today children and youngsters live in complex mediasaturated environments impacted by television, digital video recorders, computers, the Internet, iPods, printed media, et cetera. The media are inseparably part of their daily lives; this is the only world they know. Although some people may try to avoid the media, it is not really possible to do so as the media comes in different forms (multimedia) and is present almost everywhere (Hoover 2006:142). For many older people, technology is part of a development that has occurred during their lives and does not reflect the world in which they were raised. However, technological development is inherent in shaping youth culture today. Hoover (2006:205) postulates that the media forms an important basis to participate in culture and society in the contemporary world. He explains this by saying that the media is a source and context through which traditional symbols, ideas and values are made available.

From a very young age, children have access to media, especially television. The older they become, the greater the access and the wider the variety of media to which they are exposed. South Africa has experienced a 93.3\% growth in Internet users in the period between 2000 and 2008 and is currently ranked fourth in the list of Top 10 Internet-using countries in Africa, with an estimated 6.8 million Internet users (Internet World Stats 2011). The accessibility of the Internet opens a new world of information to users, but, at the same time, assumes that users have the ability and sense of responsibility not to watch and engage with negative or destructive information. The Internet provides easy access to pornography which can have far-reaching effects, especially for children and teenagers. Most people view pornography as harmful to children and therefore most countries forbid the selling of pornographic material to children. Although there are different laws in South Africa to prevent children from being exposed to pornography, we also have laws that guarantee freedom of expression, which makes the availability of sexually explicit material a controversial issue. For example, television channels frequently broadcast programmes with explicit sexual content and, even though this should - by law - only take place in the watershed period (between 21:00 and 05:00), there is no guarantee that youth are not exposed to it. Sexually explicit material is also advertised on television and can be sent to cell phones for as little as R5.00. Unfortunately, in South African households, adequate parental guidance and influence are not present, which means that youngsters have easy access to sexually explicit material without any adult guidance (Le Roux 2010:66).

Sexually explicit material can also be recorded and spread through different forms of media. A family therapist from Johannesburg reports as follows on the sexual behaviour of teenagers in South Africa:

In my practice I have seen numerous teens from as young as 11 who become involved in very disturbing sexual situations, for example teens photographing each other having sexual intercourse, orgies, having oral sex, etc and selling it as pornography on the internet. (Yoro Bodut 2006)

Similarly, a sexologist and relationship therapist based in Pretoria says she is:

not surprised that teenagers indulge in these sexual activities as it seems that 'everything goes'. With the access to media, a lack of healthy sex education, porn on the internet and cell phones, teenagers have become sexually desensitised. (Yoro Bodut 2006)

Another incident that sent shockwaves through the South African community was when two under-aged boys and a girl had sex on the Jules High School grounds in Johannesburg, after which the boys were charged with statutory rape. The unhealthy sexual behaviour of teenagers in South Africa is confirmed by Cooksey and Dooms (2010:106) when they state that sexual activity amongst young people is both high and risky in nature. They describe this sexual behaviour of teenagers as something that is not isolated, but based on the risky behaviour of youth in general, which seems to be normative (Cooksey \& Dooms 2010:107).

\section{According to Mueller (2006):}

the media and the youth are dependent on each other. The media need the youth market for economic survival and the youth need the media for guidance and nurture in a society where other societal institutions such as the family and the school do not shape the youth culture as powerfully as they once did. (p. 27)

Schultze et al. (1991:11) describe the relationship between the youth and the media as a symbiotic relationship. This relationship is kept intact, because the media see themselves as 'quasi parents' who help youth to find their way in a changing society. According to Posel (2008:14), there is a resistance in the South African adult society to talk about sex and sexual matters. Young people, on the other hand, are curious about sexual matters as they are in a developmental stage where sexual development is reaching a peak. The media zooms in on these needs of the youth and provides different forms of entertainment that will assumingly address these needs (Schultze et al. 1991:9). Enfield (2003:54) found that most teenagers obtain their sexual information from peers and the media, whilst Chapin (2000:83) argues that the media does not only provide information on sex, but also has a powerful influence on the sexual attitudes and behaviour of adolescents because of the amount of time they are exposed to the media where sexual content is 
regularly available. Similarly, Gouws, Kruger and Burger (2000:110) argue that the changing sexual attitudes and behaviour evident in the media encourage permissiveness in premarital and extramarital life. It therefore becomes clear that youngsters need guidance on how to understand what is happening to them emotionally, physically and spiritually with regard to their sexual development, as well as guidance on how to respond appropriately to these changes in their bodies which affect their whole life. Currently, it seems that the media takes note of the needs of the teenagers and speaks on these issues, including sex and sexuality, even misusing these sacred human needs for its own economic benefit, whilst other social institutions, such as families and churches, are reluctant to talk about it or, in most cases, keep quiet on the matter.

From the above discussion, it seems evident that the media has a pervasive presence in young people's lives and that violent and sexually explicit content is easily available across the various forms of the media. At the same time, it must be acknowledged that the media is a source of information on almost anything and therefore cannot be labelled as simply 'bad'. Young people rely on the media for information and education on sexual matters as this is usually not something that is discussed by parents or in churches. The question could therefore be raised: are youngsters merely passive consumers with regard to media messages on sex and sexuality? The answer is not simply 'yes' or 'no', as youth are capable of reasoning and abstract thinking. However, I argue that if the various media are the only or primary educators on sex and sexuality and there are no other voices, such as those of parents and faith communities who can put the conversation on sex and sexuality into a moral context, this conversation is heading down a destructive path. There is need for alternative voices than those of the media to guide the youth in making choices with regard to how to live out their sexuality with dignity and respect for themselves and others. Therefore, the most important question for the purpose of this article is how can we raise this conversation on sex and sexuality in a more constructive manner on the agenda of, especially, faith communities? The last section of the article will explore ways to do just that.

\section{Faith communities and sexuality}

The need to address the abovementioned question is affirmed by Cooksey and Dooms (2010) when they state:

Despite the abundance of articles written on adolescent sexual behaviour in recent decades, relatively little research address[es] the role that religion might play in affecting teen's sexual attitudes and behaviour. (p. 110)

According to Nelson (1992:17-18), the Church is afraid to speak on sexual matters - to break the silence - as there are very complex matters in this regard, such as the sexuality of single people, the ordination of members without regard for sexual orientation, the increasing pluralism of marital and family styles and the epidemic of teenage pregnancies. Furthermore, the discrepancy between Church teaching and the sexual practices of clergy lead to confusion amongst youngsters and even bring the Church into discredit in the larger society.

All these sexual matters and questions are sometimes just so diverse and complex that it seems that the Church's best response is to shy away from the issues on which there does not seems to be easy answers. Unfortunately, its silence gives others, such as the media, the chance to speak out and take the lead in the discussion and education on sexual matters. Despite the silence of the Church, there is much open debate and discussion on sexual issues today, as people have the need to express their sexuality, seek guidance and talk about it. It is necessary for faith communities to partake in this discourse and offer guidance from a biblical perspective. Having said this, it does not mean that easy answers need to be formulated for complex issues and outdated positions on sex and sexuality need to be reinforced. Sometimes there is a tendency to overemphasise the difficulties and differences on an issue and neglect the things on which there is some clarity and which could be a constructive point of departure. I would therefore like to highlight some basic points of departure and formulate them as guidelines that can be utilised by faith communities in order to become meaningful partners in the discourse on sex and sexuality today.

\section{How faith communities can become more effective partners in the discourse on sex and sexuality Faith communities as hermeneutical space for
youth education on sex and sexuality}

It is long overdue that faith communities break the silence and take responsibility to speak in new and fresh ways on the matter at hand. Sexual education without an accompanying moral education does not provide the desired and best outcome for the youth and faith communities are perhaps best positioned to put sexual education within a moral context. The Church as institution has various platforms such as youth groups, catechesis and sermons in which a space can be created for youngsters to discover biblical guidelines and gain an understanding about sex and sexuality. Faith communities can be a hermeneutical space, where questions can be asked, where being confused is not synonymous with being rejected or shut down and where youngsters can come to an understanding of God, themselves and others - a safe space where life issues, such as sexuality, can be discussed in a responsible way. In order to become this hermeneutical space, faith communities must choose not to be judgemental on the observable (empirical) behaviour of teenagers with regards to sex, but make an effort and the time to get some understanding of the worldview which constitutes the norms and values behind this behaviour. A more effective way of facilitating this engagement with youth is through dialogue. I do think it is better to engage in serious conversation with youth, rather than prescribing to them what to do. This means both parties are acknowledged and taken serious in this process. This also underscores the relational nature of youth work. I am of the opinion that in order to create this kind of honest dialogue, anthropology comes into play - in other 
words, how we view each other as dialogue partners. The 'equi-human' approach introduced by Firet (1986:156) could be of great value in this regard. According to this approach youths are viewed as equal human beings. This implies that youths are not less human than older people and cannot be treated like objects in this conversation by only being on the receiving end of information. It also counters the attitude that youth is a problem that needs to be solved. In this space the stories of youngsters need to be listened to and appreciated. This interaction and acknowledgement of one another as equals can also meet the need of adolescents to belong and be appreciated for who they are.

\section{Responsible ways of viewing sex and sexuality}

The manner of the conversation will be important and will also make a big difference in the outcome of the process. There is no reason to be judgemental or moralistic about the matter; in other words, there is no need for churches to discuss and treat sex and sexuality in a negative light, as they are sometimes prone to do. In a moralistic conversation, the focus is more on what should not be done than on a positive appreciation of sex and sexuality as God given. A more responsible view of sex and sexuality would be to be positive about it and focus on its religious dimensions (Sheffler 2008:1255). We do not have to be apologetic and explain why we are sexual beings - sexuality and sex is a normal part of our human being and therefore cannot be suppressed or ignored. According to Ellens (2006:7), the Church moralises sexuality whilst the Bible does not do that at all. The Bible celebrates sexuality as an integral part of being human, being created in the image of God. According to Kretzchmar and Hulley (1998):

Being a sexual being is a very basic element of our humanness and is closely tied to our self-understanding and the way in which we relate to others and the world around us. (p. 51)

According to Daniel Louw (2008:353), 'Sexuality touches the very fabric of human life.' It is an integral part of being human and a way of expressing intimacy. Sexuality is also a spiritual issue as it as can be described as the longing for the other. Ellens (2006:5) also points out the close link between spirituality and sexuality, in that they are both the expression of our hunger and longing for connection with each other, but also with the transcendent. The conversation and education on sex and sexuality should be more positive than the over-moralisation which could make youth feel guilty and ashamed of their sexuality. Being positive about our sexuality implies being informed about our responsibility as to how we live out our sexuality, as it is not a private matter but one that influences the community and the world at large. Furthermore, it means that we understand that sex is not only a genital function, but involves our total being. The risky sexual behaviour of youth, such as engaging in sexual intercourse at a very young age (e.g. 12-13 years old) and having multiple sexual partners, gives the impression that they are misinformed on the matter (Cooksey \& Dooms 2010:106).

In this conversation with youth we must be clearer on the responsibility of being in the image of God as a sexual being.
Teenagers need to learn to take responsibility for their lives and faith communities can be of great help in this regard. Whilst the emphasis today is on personal pleasure and fulfilment, faith communities have an alternative message of sacrifice, discipline and love for the neighbour. This message is of importance to sexuality as we need to respect ourselves and others in expressing and enjoying our sexuality. Sex is not just an act for pleasure without commitment and love, as is sometimes portrayed by the media. It is a matter of positive and constructive relationships. As Ellens (2006: 149-150) postulates, 'Healthy human sex and love are always intimately connected. Sex and love are both expressions of the heart of God.' This is a very important part of the education on sexuality, as teenagers engage in very risky sexual behaviour without understanding the consequences. According to Kretzchmar and Hully (1998:52), there are only two options with regard to our sexuality and sex: either give yourself over to sexual desires, or completely repress your sexual desire. This viewpoint leads to an oversimplification of sexuality, as we cannot ignore it but, at the same time, there is more to us then just being sexual beings. The second of these two options also leads to the common myth that the self and the body can be separated. This kind of dualism when it comes to sex and sexuality is not helping us in any way. Sexuality and sex is not a private matter but a communal one, because it is about how we relate to God, to ourselves and to others. Faith communities have the opportunity to teach and discuss sexuality and sex in a responsible way by unmasking these unbiblical myths about sex and sexuality.

\section{Family as primary conversation partners and educators of youth}

Although we know that the media has a very big influence on the youth today, research shows that parents and family life still do have the greatest influence on the life of children (McDowell 2006:59-60). According to Nel (2000:19), the family is the primary context where children come to an understanding of the world, themselves and God. The theological understanding of family in this article is best defined by Anderson (2001), namely that:

the mutual existence of human beings constitutes the essential core of what the Bible means by family - mutual care - where development in self-identity, personal maturity acquiring of moral values and spiritual formation take place. (p. 260)

Who provides this care is not important; what is important is the existence of this social context, where youth could be nurtured and cared for. Family is viewed as more than a certain structure, but as process where identity, character and spiritual formation can take place (Anderson 2001: 260-263). Some of the reasons for the lack of sufficient parental guidance on sex and sexuality to youth include, (1) parents themselves do not have enough knowledge on the matter, (2) parents do not want to talk about sensitive matters, (3) they are afraid they might give incorrect answers, (4) they see sexual education as the task of the school, (5) they are not often at home and (6) have communication problems and do not know how to communicate effectively with teenagers (Titus 2005:85). From these reasons it seems evident that parents need assistance in raising their children 
and even more so in this media-saturated era. The faith community can play a vital role in educating and assisting parents in their task as spiritual leaders, especially in regards to their children. Auten (1990) provides an indication of how powerfully influential the attitudes of parents are on the youth, especially with regard to sex and sexuality, when he states:

Most of the attitudes and values that cause sexual problems among young couples, can be traced back to attitudes, behaviour and values that are either consciously or unconsciously absorbed from parents. (p. 86)

Parents' expression of their sexuality can thus be viewed as one of the major contributors to sex education for youth. Most of the time, the reality is that parents grew up during a period when sex and sexuality were not openly discussed and thus they are not always sure how to have this conversation with their children. Faith communities can be of help to parents in assisting them to be more comfortable with their own sexuality and learn skills in how to be open to have this kind of conversation with their children. However, the Church can never take over the role and responsibility of the parents, but needs to support the parents' role as primary educators of the youth. A partnership between faith communities and family is needed to address the moral education of the youth. In the media-saturated culture in which they live, youngsters are connected with people around the world, with whom they do not necessarily have a personal relationship. If parents do not make quality time for their children to create a local, safe space where youth have the courage and opportunity to ask about sex and sexuality, the situation will continue to deteriorate and youth will turn to the media and peers as their primary educators on these issues. At the same time, it is not possible to avoid the media and its possible influence on the sexual attitudes and behaviour of the youth. Therefore, my argument within this article is to urge faith communities and parents to provide an alternative voice on the matter.

\section{Conclusion}

Faith communities today face different challenges regarding sexuality, including HIV and AIDS, sexual violence, homosexuality, different forms of marriage and family life and the influence of the media, et cetera. This calls for a revisiting of the Church's stance on the matter, as current views do not seem to offer relevant or sufficient guidance on the questions asked. It would be helpful if churches are aware of their own theological history on sexuality and sex and how it influences their message on sexuality and sex today. Churches do still have various platforms and structures, such as catechesis, through which a lot of youngsters pass in their life time, which create opportunities to engage with youngsters on life issues such as sexuality. Faith communities are therefore urged to make more effective use of these opportunities and take their rightful place in the current discourse on sex and sexuality.

\section{Acknowledgements Competing interests}

The author declares that she has no financial or personal relationship(s) which may have inappropriately influenced her in writing this article.

\section{References}

Anderson, R.S., 2001, The shape of practical theology: Empowering ministry with theological Praxis, Intervarsity Press, Downers Grove, IL.

Auten, R.D., 1990, The role of the Church in helping early adolescents deal with issues of sex and sexuality, University Microfilms International, Ann Arbor, MI.

Bishops' Group, 2003, Some issues in human sexuality: A guide to the debate, Church Publishing House, London.

Chapin, J.R., 2000, 'Adolescent sex and mass media: A developmental approach', Journal of Adolescence 35(140), 799-811.

Cooksey, E. \& Dooms, T., 2010, 'The role of religion in the sexual life of teens', in P. Dandelion \& S. Collins-Mayo (eds.), Religion and youth, pp. 105-111, Ashgate Publishing Company, Burlington, VT.

Ellens, J.H., 2006, Sex in the Bible: A new consideration, Praeger Publishers, Westport, CT.

Enfield, L.C., 2003, 'Sexual attitudes and behavioural patterns of adolescents in an urban area in the Western Cape', unpublished MEd thesis, Department of Social Work, Stellenbosch University.

Firet, J., 1986, Dynamics in pastoring, Eerdmans, Grand Rapids, MI.

France, A., 2007, Understanding youth in late modernity, Intervarsity Press, London. http://dx.doi.org/10.1080/13676260701690410

France, A., 2008, 'Risk factors analysis and the youth question', Journal of Youth Studies 11(1), 115

Gouws, E., Kruger, N. \& Burger, S., 2000, The adolescent, 2nd edn., Heinemann Publishers, Sandown.

Hall, S., 1931, Adolescence: Its psychology and its relations to physiology, anthropology, sociology, sex, crime, religion and education, Appleton and Company, New York, NY.

Hoover, S.T., 2006, Religion in the media age, Routledge, Abingdon.

Internet World Stats, 2011, Internet usage statistics for Africa, viewed 02 December 2011, from http://www.internetworldstats.com/stats1.htm

Kotesky, R.L., 1991, 'Adolescence as a cultural invention', in D. Ratcliff \& J.A. Davies (eds.), Handbook of youth ministry, pp. 42-69, R.E.P. Books, Birmingham.

Kretzschmar, L. \& Hulley, L. (eds.), 1998, Questions about life \& morality: Christian ethics in South Africa today, JL van Schaik Religious Books, Pretoria.

Krinsky, C. (ed.), 2008, Moral panics over contemporary children and youth, Ashgate Publishing Limited, Farnham.

Le Roux, L., 2010, 'Pornography: Human right or human rights violation?', HTS Theological Studies 66(2), 41-48.

Louw, D., 2008, Cura Vitae: Illness and the healing of life, Lux Verbi, Wellington.

McDowell, J., 2006, The last Christian generation, Green Key Books, Holiday, FL.

McRobbie, A., 1993, 'Shut up and dance: Youth culture and changing modes of femininity',Cultural Studies 7, 406-426. http://dx.doi. org/10.1080/09502389300490281

Miles, S., 2000, Youth lifestyles in a changing world, Open University Press, Philadelphia, PA.

Mueller, W., 2006, Engaging the soul of youth culture: Bridging teen worldviews and Christian truths, Zondervan Publishing House, Downers Grove, IL.

Muncie, J., 2004, Youth and crime, Sage, London.

$\mathrm{Nel}, \mathrm{M} ., 2000$, An inclusive congregational approach to youth ministry, Kitskopie, Pretoria.

Nelson, J.B., 1992, Body theology, Westminster Press, Louisville, KY.

Orr, L., 2004, 'Violence 4-Ever? Looking for God in the global sex market', Contact $145,5-20$.

Posel, D., 2008, Getting the nation talking about sex: Reflections on the politics and nation-building in Post-Apartheid South Africa, viewed 20 May 2011, from http:// nation-building in Post-Apartheid South Africa, viewed 20
wiserweb.wits.ac.za/PDF\%20Files/sex\%20-\%20posel.PDF

Root, A., 2007, Revisiting relational youth ministry: From a strategy of influence to a theology of incarnation, Intervarsity Press, Downers Grove, IL.

Scheffler, E., 2008, 'Eros as godsdiens of die religieuse viering van seks', HTS Teologiese Studies/Theological Studies 64(3), 1255-1277.

Schultze, Q.J., Anker, R.M., Bratt, D.J., Romanowski, W.D., Worst, J.W. \& Zuidervaart, L., 1991, Dancing in the dark: Youth popular culture and the electronic media, Eerdmans, Grand Rapids, MI.

Titus, C.M., 2005, " $n$ Multi-sektorale benadering tot seksualitietsopvoedings programme vir adolessente', unpublished MEd thesis, Department of Social Work, Stellenbosch University.

Yoro Badat, N.-J., 2006, SA teen sex shock, IOL News, viewed 18 March 2011, from http://www.iol.co.za/news/south-africa/sa-teen-sex-shock-1.269062 